\title{
Carbon Dioxide Reduction on a Metal-Supported Solid Oxide Electrolysis Cell
}

\author{
Yuichi NUMATA, ${ }^{1)}$ Keito NAKAJIMA, ${ }^{1)}$ Hiroki TAKASU ${ }^{2)}$ and Yukitaka KATO ${ }^{2 / *}$ \\ 1) Graduate Major in Nuclear Engineering, Tokyo Institute of Technology, 2-12-1-N1-22, Ookayama, Meguro-ku, Tokyo, 152- \\ 8550 Japan. \\ 2) Laboratory for Advanced Nuclear Energy, Institute of Innovative Research, Tokyo Institute of Technology, 2-12-1-N1-22, \\ Ookayama, Meguro-ku, Tokyo, 152-8550 Japan.
}

(Received on June 13, 2018; accepted on November 19, 2018)

\begin{abstract}
Using iACRES, which is an ironmaking system based on the Active Carbon Recycling Energy System concept, to reduce or recycle $\mathrm{CO}_{2}$ emitted from ironmaking processes, we electrolyzed $\mathrm{CO}_{2}$ with a metalsupported solid oxide electrolysis cell (MS-SOEC) capable of providing a large cell surface area for the processing of large amounts of $\mathrm{CO}_{2}$. The MS-SOEC current-density-voltage (I-V) curves reveal a change in slope at around $0.8 \mathrm{~V}$, which is the theoretical decomposition voltage of $\mathrm{CO}_{2}$. The $\mathrm{CO}$ production rate was $0.88 \mu \mathrm{mol} \mathrm{cm}{ }^{-2} \mathrm{~s}^{-1}$ when $2.0 \mathrm{~V}$ was applied between the cathode and the anode at $800^{\circ} \mathrm{C}$, while that for $\mathrm{O}_{2}$ was $0.44 \mu \mathrm{mol} \mathrm{cm}{ }^{-2} \mathrm{~s}^{-1}$, which is consistent with the stoichiometry for $\mathrm{CO}_{2}$ electrolysis. The Faraday efficiency was $48 \%$ at $900^{\circ} \mathrm{C}$. Gas was observed to leak from the cell; this leakage will need to be overcome through improvements in the layer-production process in order to achieve an efficiency close to $100 \%$. On the basis of the cell-based experimental results, the feasibility of a blast furnace based on iACRES and driven by an HTGR (high-temperature gas-cooled reactor) was evaluated. To reduce $\mathrm{CO}_{2}$ emissions by $30.0 \%$, the required MS-SOEC surface area was estimated to be $8.30 \times 10^{4}$ and $3.98 \times 10^{4} \mathrm{~m}^{2}$ with 968 and 480 MWth of HTGR thermal output under Faraday efficiency of $48 \%$ and $100 \%$, respectively. We confirmed that iACRES using MS-SOEC contributes to realizing low-carbon ironmaking by recycling $\mathrm{CO}_{2}$ and reducing its emissions into the atmosphere.
\end{abstract}

KEY WORDS: carbon dioxide; carbon monoxide; metal-support; solid oxide electrolysis cell; carbon recycling.

\section{Introduction}

Ironmaking process and chemical industries emit large amount of carbon dioxide $\left(\mathrm{CO}_{2}\right)$ that causes global warming. Fossil-energy resources are imported in some countries, which economically suppresses those industries. To solve these problems, a new energy system referred to as the "Active Carbon Recycling Energy System" (ACRES) ${ }^{1)}$ has been introduced. $\mathrm{CO}_{2}$ is reduced chemically and recycled as a process material in ACRES. Carbon monoxide (CO) is a recycling-medium candidate for ACRES, as shown in Eq. (1), since $\mathrm{CO}$ has a higher exergy ratio $(\Delta G / \Delta H)$ than hydrogen $\left(\mathrm{H}_{2}\right)$ produced through the reduction of water, and other hydrocarbons.

$$
\mathrm{CO}_{2} \rightarrow \mathrm{CO}+0.5 \mathrm{O}_{2} \Delta H=283 \mathrm{~kJ} \mathrm{~mol}^{-1}
$$

The co-product oxygen is also a useful industrial material. The ironmaking process that applies ACRES is referred to as "iACRES" (smart ironmaking process based on ACRES). ${ }^{2)}$ Exhausted $\mathrm{CO}_{2}$ from the iACRES-based ironmaking process is recovered through a separation process, reduced to $\mathrm{CO}$,

\footnotetext{
* Corresponding author: E-mail: yukitaka@lane.iir.titech.ac.jp DOI: https://doi.org/10.2355/isijinternational.ISIJINT-2018-430
}

and reused in the process through recycling.

The reduction of $\mathrm{CO}_{2}$ to $\mathrm{CO}$ is a key technology for the establishment of iACRES. $\mathrm{CO}_{2}$ can be reduced to $\mathrm{CO}$ by a solid oxide electrolysis cell (SOEC) in which $\mathrm{CO}_{2}$ electrolysis is carried out by the reverse operation of a solid oxide fuel cell (SOFC). A proposed iACRES for ironmaking is shown in Fig. 1. $\mathrm{CO}_{2}$ is separated from the exhaust gas of the ironmaking process, and $\mathrm{CO}$ is regenerated by the SOEC. Since regenerated $\mathrm{CO}$ is recirculated in

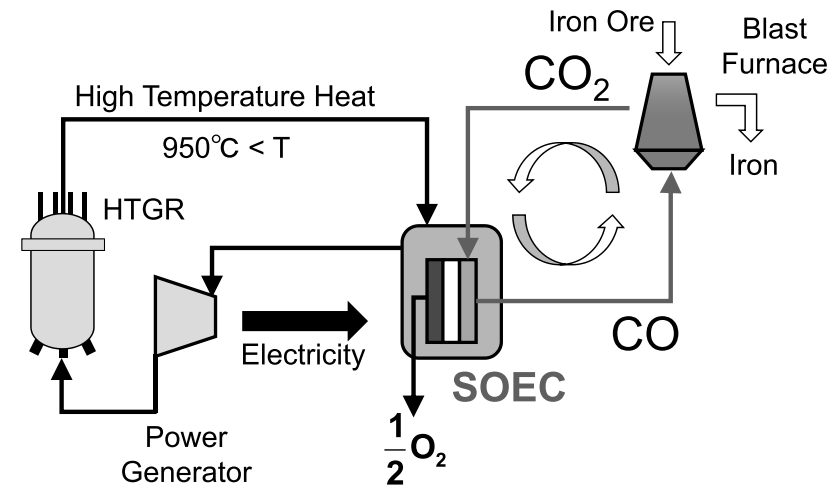

Fig. 1. Schematic of the iACRES concept. 
the process, the quantity of coke (reducing agent) required is reduced. As an energy source for driving iACRES, renewable energy such as solar and wind power, hightemperature gas-cooled reactors (HTGRs), ${ }^{3)}$ and the waste heat from high-temperature industrial processes have been considered. In particular, HTGR is the main candidate for iACRES because it produces heat at high temperatures of up to $950^{\circ} \mathrm{C}$, which are well matched to the needs of the SOEC process.

$\mathrm{CO}_{2}$ electrolysis by SOEC has already been demonstrated. $^{4)}$ A SOEC consists of anode/electrolyte/cathode layers. A conventional cell is constructed from ceramic materials because a ceramic electrolyte material has an efficient oxygen-ion $\left(\mathrm{O}^{2-}\right)$ conductivity. Disk-type ceramic SOEC $\mathrm{CO}_{2}$ electrolysis has been demonstrated, ${ }^{6)}$ which led to the conclusion that a cell surface area of the order of $10^{4}$ $\mathrm{m}^{2}$ was required for the SOEC to achieve a blast-furnacetype iACRES. ${ }^{6}$

However, the ceramic material in a SOEC is vulnerable to thermal and mechanical shock, which makes it difficult to create a cell structure with a large surface area. To overcome this, we developed a metal-supported SOEC (MS-SOEC) that can achieve a large surface area. This study experimentally examined the $\mathrm{CO}_{2}$-electrolysis performance of the MSSOEC, and its applicability to an ironmaking system based on iACRES was evaluated on the basis of the experimental SOEC results.

\section{Experimental}

Figure 2 displays the structure of the proposed MSSOEC, which we refer to as "NYG4". The SOEC was constructed on a 20 -mm-diameter porous metal support, and has the following four layers on the metal substrate: anode | electrolyte | cathode | diffusion-barrier layer.

The porous metal support (prepared by Nippon Seisen Co., Ltd.) was made from SUS430 and SUS430 mesh with mesh-wire diameter of less $10 \mu \mathrm{m}$, and was welded at the center of the support. The anode, electrolyte, cathode, and diffusion-barrier layers were $\mathrm{La}_{0.6} \mathrm{Sr}_{0.4} \mathrm{Co}_{0.2} \mathrm{Fe}_{0.8} \mathrm{O}_{3-\delta}$ (LSCF), yttria-stabilized zirconia (YSZ), NiO-YSZ, and $\mathrm{La}_{0.6} \mathrm{Sr}_{0.2} \mathrm{Ca}_{0.2} \mathrm{CrO}_{3}$ (LSCC), respectively. All layers are formed by the atmospheric plasma spray method (APS) (sprayed by TOCALO Co., Ltd.).

Figure 3 shows photographic images of the outside of the developed MS-SOEC, and an enlarged view of the cell mesh.

The MS-SOEC electrolyzes carbon dioxide by applying voltage on the cell, ${ }^{5)}$ as shown in Fig. 4.

$\mathrm{CO}_{2}$ passes through the pores of the mesh and the diffusion-barrier layer, and reaches the cathode layer to receive electrons for the production of $\mathrm{CO}$ and $\mathrm{O}^{2-}$, according to:

$$
\mathrm{CO}_{2}+2 \mathrm{e}^{-} \rightarrow \mathrm{CO}+\mathrm{O}^{2-}
$$

$\mathrm{O}^{2-}$ is transported to the anode through the electrolyte and $\mathrm{O}_{2}$ is generated:

$$
\mathrm{O}^{2-} \rightarrow 0.5 \mathrm{O}_{2}+2 \mathrm{e}^{-}
$$

Equation (1) is established through the progression of Eqs. (2) and (3).

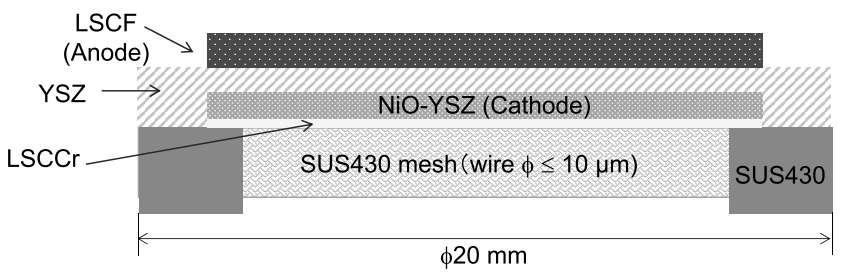

Fig. 2. Structure of the NYG4 MS-SOEC.

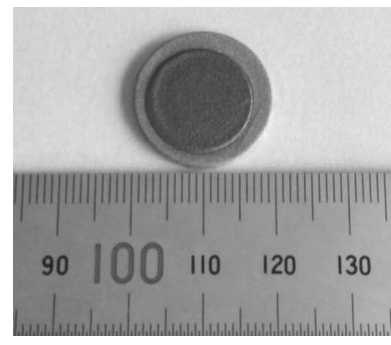

(a)

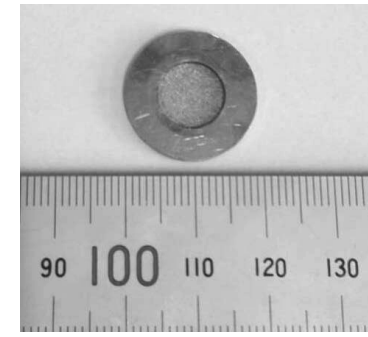

(b)

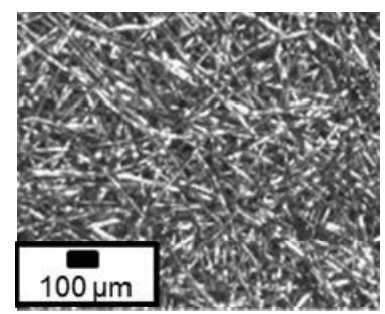

(c)
Fig. 3. Photographic images of the developed MS-SOEC: (a) anode side, (b) cathode side, and (c) enlarged view of the cell mesh.

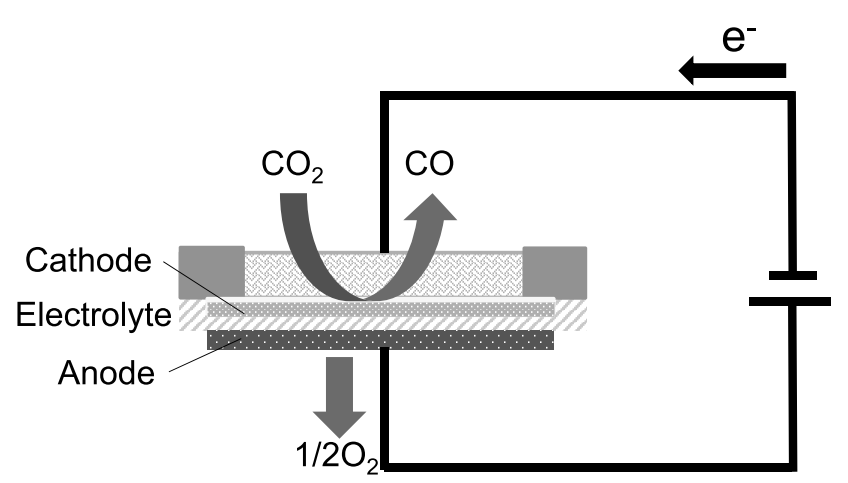

Fig. 4. MS-SOEC principles.

\section{Experimental}

\subsection{SOEC Apparatus}

The experimental apparatus was built to measure the performance of the SOEC. Figure 5 displays the experimental SOEC system, while Fig. 6 shows a schematic of the reactor cross-section. The cell is held by two outer alumina tubes with glass seal rings, and the reaction gases are supplied through the inner tubes.

$\mathrm{CO}_{2}$ and $\mathrm{N}_{2}$ are supplied to the cathode side as the feed gas; $\mathrm{N}_{2}$ is also supplied to the anode as a sweep gas for the generated $\mathrm{O}_{2}$. Gas compositions of the effluent gases from both electrodes were analyzed using a TCD gas chromatograph (GC-8AIT, Shimadzu CO.).

A potentiostat/galvanostat (HAL3001, Hokuto Denko), ammeter (HM-104A, Hokuto Denko), and voltmeter (HE- 
104A, Hokuto Denko) were used to measure the electrochemical performance of the cell. Both electrical currents were collected by $\mathrm{Pt}$ mesh attached to the inner tubes, as shown in Fig. 6. The glass seal rings set between the cell and the alumina tube were melted at $950^{\circ} \mathrm{C}$ in advance to seal the cell to the tube in order to protect against gas leakage.

\subsection{Electrolysis Process}

Prior to any experiment, the NiO-YSZ in the cathode was reduced to Ni-YSZ with $\mathrm{H}_{2}$ at $800^{\circ} \mathrm{C}$ for $1.0 \mathrm{~h}$. During

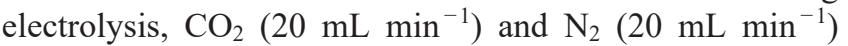
were supplied to the cathode side, and $\mathrm{N}_{2}\left(30 \mathrm{~mL} \mathrm{~min}^{-1}\right)$ was supplied to the anode side. Current-voltage curves (I-V curves) were obtained by increasing the cathode-reference voltage over the $0.0-2.0 \mathrm{~V}$ range, at 800 and $900^{\circ} \mathrm{C}$, in 0.1 $\mathrm{V}$ steps. The production rates of $\mathrm{CO}$ and $\mathrm{O}_{2}$ were calculated from gas-composition analyses and flow rates.

\subsection{Cell-Leakage Evaluation}

The electrolyte layer produced by the APS method was prepared by the agglomeration of primary particles; consequently some porous paths still exist in this layer that facilitate the leakage of some gas through the whole cell. This leakage will be remediated in the future by improving the APS processing conditions that determine the thickness

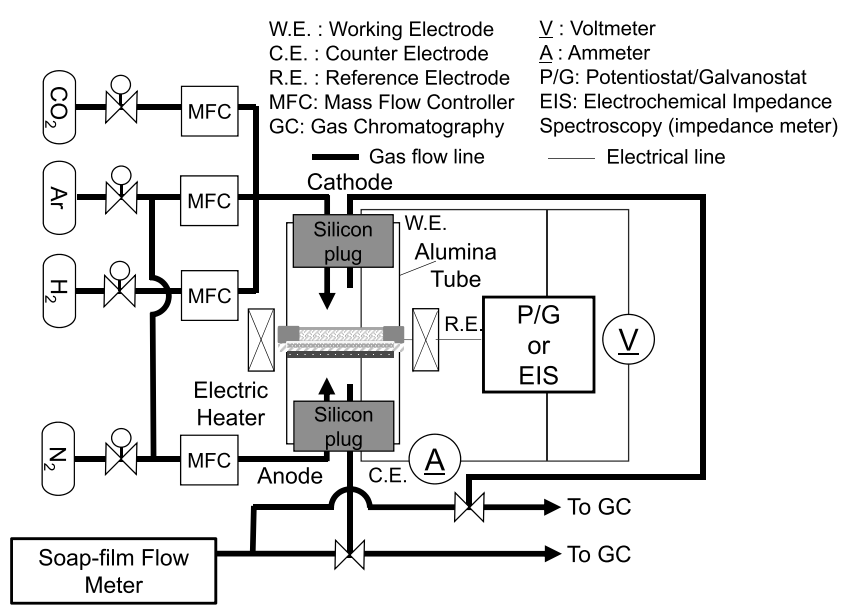

Fig. 5. Schematic diagram of the experimental SOEC apparatus.

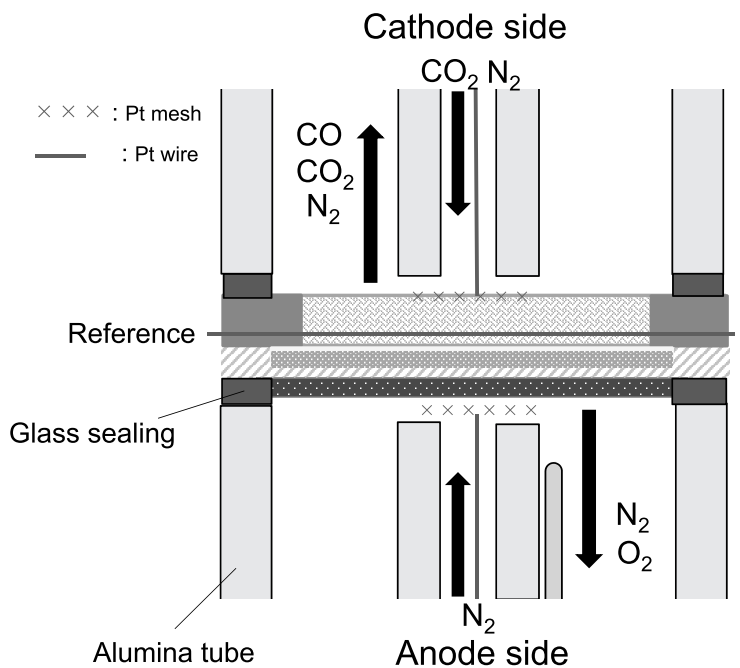

Fig. 6. Reactor cross-section. of the layer, and the temperature of the plasma used to produce the layer. However, we first evaluated the current cell in order to demonstrate this new MS-SOEC process. The leakage factor, LF [\%], was determined to show the relative level of leakage. For the MS-SOEC shown in Fig. 6, the cathode and anode sides were supplied with $\mathrm{Ar}(47.5 \mathrm{~mL}$ $\min ^{-1}$ ) and $\mathrm{N}_{2}\left(30 \mathrm{~mL} \mathrm{~min}^{-1}\right)$, respectively. $\mathrm{N}_{2}$ that leaked to the cathode side from the anode side was analyzed by gas chromatography, and the LF was calculated as the $\mathrm{N}_{2}$ molar concentration at the cathode side in the $\mathrm{Ar}+\mathrm{N}_{2}$ mixture. As will be discussed in the following section about the SEM image in Fig. 10, some part of the boundary between cathode and electrolyte in the cell showed peeling-off which had possibility to cause cell reactivity fall. Then, the measurements in this study were performed after reaching stable condition to eliminate the effect of the initial change in the cell status.

\section{Results and Discussion}

\subsection{Electrochemical Performance of the SOEC}

Figure 7 displays I-V curves for NYG4 at 800 and $900^{\circ} \mathrm{C}$; the $\mathrm{LF}$ was $5.6 \%$ at $800^{\circ} \mathrm{C}$. This graph shows that the slope changes at around $0.5-1.0 \mathrm{~V}$, which almost close to the theoretical decomposition voltage, $V_{\text {th }}$, of $0.98 \mathrm{~V}$ for $\mathrm{CO}_{2}$, suggesting that $\mathrm{CO}_{2}$ electrolysis has occurred. $V_{\text {th }}$ was defined by the following equation:

$$
V_{\mathrm{th}}=\frac{\Delta G}{n F}
$$

, where $\Delta G\left[\mathrm{~kJ} \mathrm{~mol}^{-1}\right], n[-]$ and $F\left[\mathrm{C} \mathrm{mol}^{-1}\right]$ are the Gibbs's free energy for Eq. (1), the moles of migrated electrons in Eq. (1) of 2 and the Faraday constant equivalent to $96500 \mathrm{C} \mathrm{mol}^{-1}$, respectively.

A current density of $353.5 \mathrm{~mA} \mathrm{~cm}{ }^{-2}$ was flowed between the cathode and anode at $4.82 \mathrm{~V} / 800^{\circ} \mathrm{C}$; similarly, $339.8 \mathrm{~mA}$ $\mathrm{cm}^{-2}$ was required at $4.38 \mathrm{~V} / 900^{\circ} \mathrm{C}$.

Figure 8 shows the effect of current density on the $\mathrm{CO}$ and $\mathrm{O}_{2}$ production rates. The $\mathrm{CO}$ production rate was 0.88

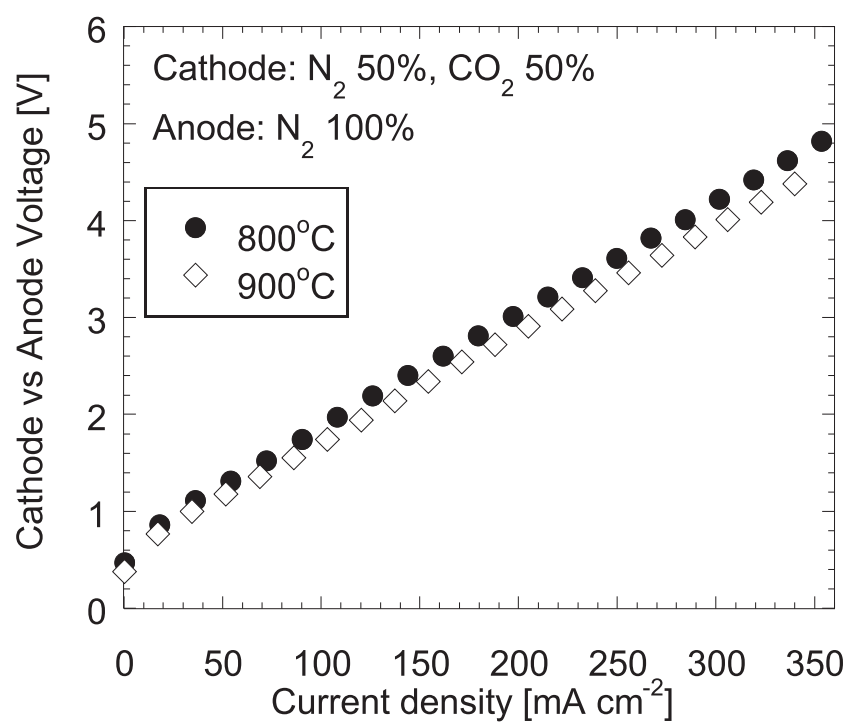

Fig. 7. Current-density-voltage curves for NYG4. C-R: voltage between the cathode and the reference; C-A: voltage between the cathode and the anode. 
$\mu \mathrm{mol} \mathrm{cm} \mathrm{cm}^{-2} \mathrm{~s}^{-1}$ at a current density of $353.5 \mathrm{~mA} \mathrm{~cm}^{-2}$ at $800^{\circ} \mathrm{C}$; similarly, the $\mathrm{O}_{2}$ production rate was $0.44 \mu \mathrm{mol}$ $\mathrm{cm}^{-2} \mathrm{~s}^{-1}$ under the same conditions. The theoretical $\mathrm{CO}$ and $\mathrm{O}_{2}$ production rate in Fig. 8 depend on current density, a consequence of Faraday's electrolysis law. The Faraday efficiency is defined by the following equation:

$$
\text { Faraday efficiency }=\frac{\text { Production rate }}{\text { Theoretical value }}
$$

In addition, the theoretical value is given by the following equation:

$$
\text { Theoretical value }\left(\mu \mathrm{mol} \mathrm{s} \mathrm{cm}^{-2}\right)=\frac{i}{n F}
$$

where $i$ is the current density [ $\left.\mathrm{A} \mathrm{cm}^{-2}\right], n$ is the number of

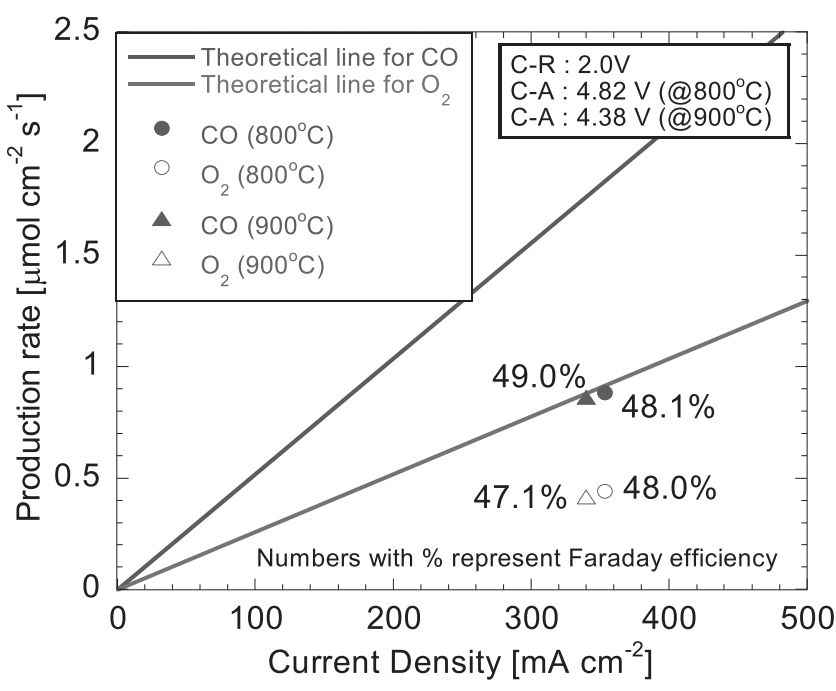

Fig. 8. $\mathrm{CO}$ and $\mathrm{O}_{2}$ production rates as functions of current density for NYG4.

(a)

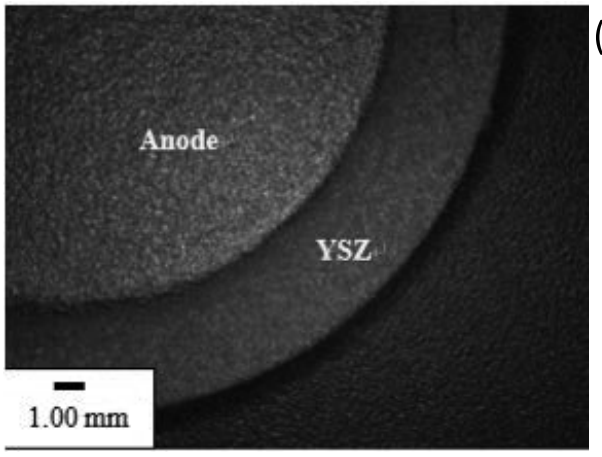

(c)

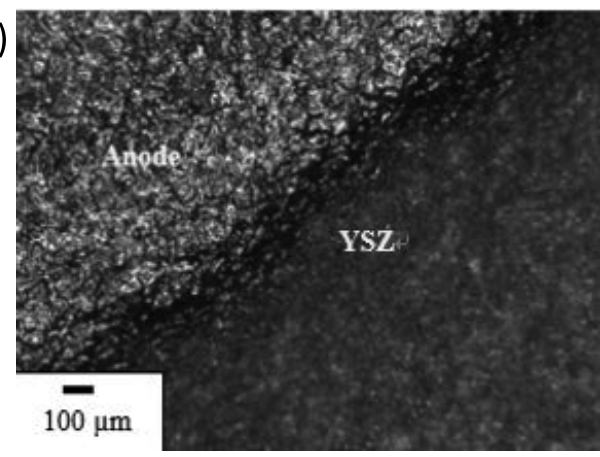

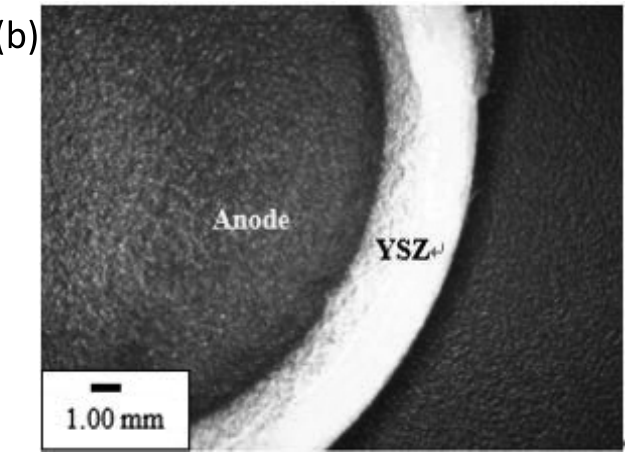

reactive electrons [-]. When calculating the $\mathrm{CO}$ production rate, $n$ in Eq. (6) is equal to 2, while $n=4$ for $\mathrm{O}_{2}$. The calculated Faraday efficiencies of $48.1 \%$ for $\mathrm{CO}$ and $48.0 \%$ for $\mathrm{O}_{2}$ (Fig. 8) are almost identical, which is consistent with the $\mathrm{CO}_{2}$-reduction stoichiometry and demonstrates that $\mathrm{CO}_{2}$ reduction proceeds on the MS-SOEC. We ascribe the observation that the Faraday efficiency is less than $100 \%$ to the reformation of $\mathrm{CO}_{2}$ from leaked $\mathrm{CO}$ and $\mathrm{O}_{2}$, although the amount of reformed $\mathrm{CO}_{2}$ could not be evaluated using our apparatus. Remediation of this leakage through improvements in the layer-production process is required to achieve values close to $100 \%$, which is the focus of our next study.

Figure 9 shows digital microscopy images of the cell surface before and after the experiment. The surface exhibited no cracks or breaks like ceramic materials, either before or after the experiment, suggesting that this cell was more durable physically than the ceramic-supported equivalent. SEM images of the cross-section of the cell after SOEC experiment are shown in Fig. 10. It is anxious that the boundary between anode and electrolyte has possibility to generate $\mathrm{SrZrO}_{3}$ and $\mathrm{La}_{2} \mathrm{Zr}_{2} \mathrm{O}_{7}$ during the reaction, and also cathode and mesh-wire tend to react with $\mathrm{CO}$. The boundaries between every layers can be observed clearly and every layers show homogeneous structures, then, it was though that every layers kept original structure without side reactions during that reaction periods. However, some part of the boundary between cathode and electrolyte showed peelingoff which had possibility to cause cell reactivity fall. It was required to clarify the peeling-off generation cause and to remove the peeling-off between these layers by improvement of layer production procedure.

\subsection{Evaluation of iACRES Using the Experimental Results}

Based on above results, we evaluated a process that com-

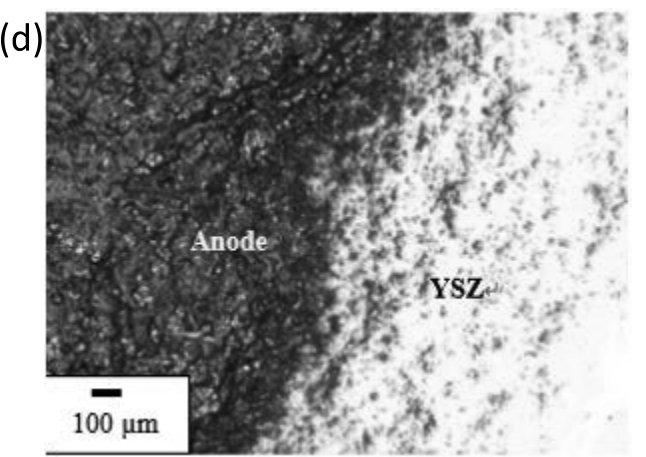

Fig. 9. Digital images of the NYG4 MS-SOEC surface: (a) before the experiment and (b) after the experiment; (c) and (d) enlargements of the images in (a) and (b), respectively. 


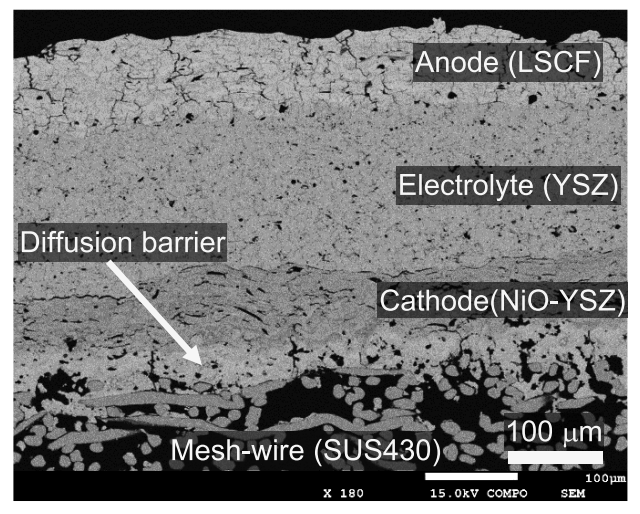

(a)

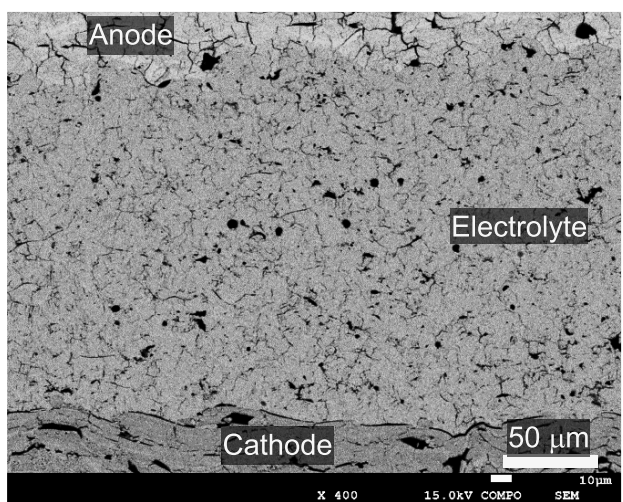

(b)

Fig. 10. SEM images of cross-section of the NYG4 MS-SOEC after SOEC experiment (a) Whole layers, (b) Cathode/ electrolyte/Anode layers.

Table 1. Assumed specifications of the furnace used for the iACRES model based on a commercial blast furnace. ${ }^{9)}$

\begin{tabular}{cc}
\hline Annual pig-iron production $\left[\mathrm{Mt} \mathrm{y}^{-1}\right]$ & 2.5 \\
Blast furnace gas (BFG) emitted per pig-iron $\left[\mathrm{Nm}^{3} \mathrm{t}^{-1}\right]$ & $1.53 \times 10^{3}$ \\
$\mathrm{CO}_{2}$ emitted per pig-iron $\left[\mathrm{Nm}^{3} \mathrm{t}^{-1}\right]$ & 350 \\
Total $\mathrm{CO}_{2}$ emissions $\left[\mathrm{Nm}^{3} \mathrm{~s}^{-1}\right]$ & 27.7 \\
$\mathrm{CO}_{2}$ content in BFG [vol.\%] & 22.8 \\
$\mathrm{CO}$ content in BFG [vol.\%] & 22.0 \\
$\mathrm{H}_{2}$ content in BFG [vol.\%] & 4.20 \\
$\mathrm{BFG}$ outlet temperature $\left[{ }^{\circ} \mathrm{C}\right]$ & 157 \\
\hline
\end{tabular}

Table 2. Assumed HTGR operating conditions for the iACRES model based on the GTHTR-300. ${ }^{8)}$

\begin{tabular}{cc} 
Reactor thermal power $[\mathrm{MWth}]$ & 600 \\
Reactor core coolant & Helium gas \\
Core coolant flow $\left[\mathrm{kg} \mathrm{s}^{-1}\right]$ & 439 \\
Core inlet temperature $\left[{ }^{\circ} \mathrm{C}\right]$ & 587 \\
Core outlet temperature $\left[{ }^{\circ} \mathrm{C}\right]$ & 850 \\
Core coolant pressure $[\mathrm{MPa}]$ & 6.9 \\
Core power density $\left[\mathrm{W} \mathrm{mL}^{-1}\right]$ & 5.4 \\
Power conversion efficiency $[\%]$ & 45 \\
Electricity production $[\mathrm{MWe}]$ & 270 \\
\hline
\end{tabular}

bines MS-SOEC and iACRES for use in blast-furnace-class ironmaking. We assumed that part of the $\mathrm{CO}_{2}$ generated from the furnace was reduced into CO by the MS-SOEC, and the heat and electricity generated from an HTGR with a $850^{\circ} \mathrm{C}$ secondary heat output and a $600 \mathrm{MWth}$ heat output capacity $\left(\right.$ GTHTR- $300^{8)}$ ) were used for SOEC electrolysis. $\left.{ }^{8}\right)$ We calculated the required thermal output power of the HTGR and the cell surface area of the SOEC are necessary for the iACRES process.

The furnace specifications are based on those of a commercial large-scale blast furnace that produces pig iron at $2.5 \mathrm{Mt}$ year $^{-1}$; Table 1 lists the furnace model specifications based on this blast furnace. ${ }^{9)}$ The experimental electrolysis data from the SOEC at $800^{\circ} \mathrm{C}$ was employed for the MS-SOEC in this evaluation. Table 2 lists the HTGR specifications based

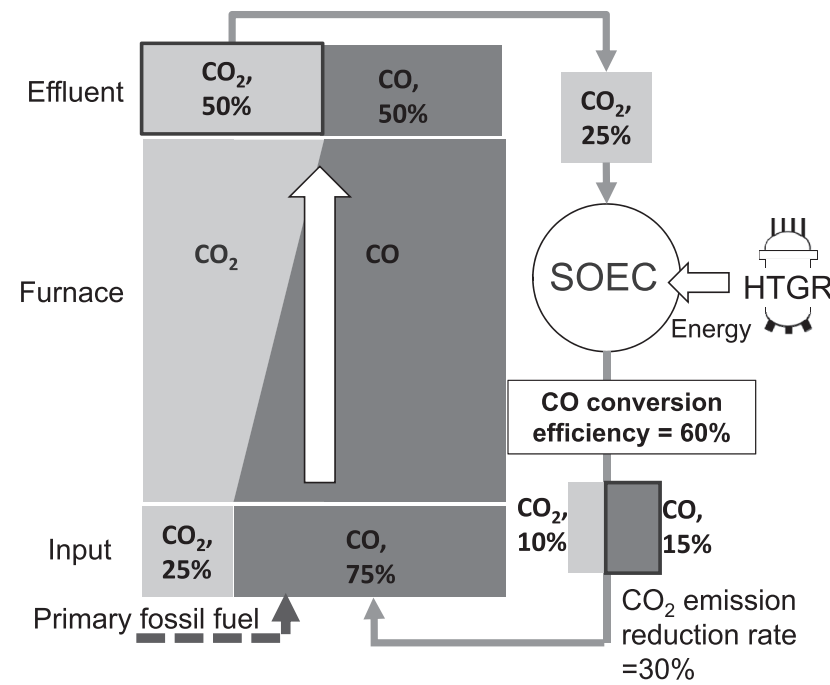

Fig. 11. $\mathrm{CO}_{2}$ balance in the iACRES model furnace.

on the GTHTR-300. The $\mathrm{CO}_{2}$-recycle balance in the iACRES model is shown in Fig. 11. Half of the $\mathrm{CO}_{2}$ generated from the furnace is recovered, while $60 \%$ of the $\mathrm{CO}_{2}$ is reduced to $\mathrm{CO}$ by the MS-SOEC, and the generated mixed $\mathrm{CO}$ and $\mathrm{CO}_{2}$ gas is supplied to the furnace as a part of the reduction gas; $30 \%$ of the total $\mathrm{CO}_{2}$ is reduced to $\mathrm{CO}$ in the iACRES system. The MS-SOEC performance, based on the calculations for iACRES and the experimental data for NYG4, is shown in Table 3, assuming a Faraday efficiency of $48 \%$ as a measured value and $100 \%$ as a theoretical value. The overall simulation conditions and estimated values are shown in Fig. 12.

Table 4 shows the calculated results for the iACRES model; to achieve a reduction in $\mathrm{CO}_{2}$ emissions of $30 \%$, thermal output of 968 and 480 MWth from HTGR are required, and the necessary MS-SOEC surface area is calculated to be $8.30 \times 10^{4}$ and $3.98 \times 10^{4} \mathrm{~m}^{2}$ under the efficiency of $48 \%$ and $100 \%$ as shown in Case 1 and 2, respectively. Improvement of Faraday efficiency was a practical subject for reduction of thermal power demand and required cell surface area. Then, the power density of the MS-SOEC needs to be enhanced through improvements in cell design in order to reduce further the surface area. This study reveals the potential scale of iACRES for realizing low-carbon ironmaking by recycling $\mathrm{CO}_{2}$ and reducing $\mathrm{CO}_{2}$ emissions into the atmosphere. 
Table 3. MS-SOEC performance using the calculations for iACRES based on experimental data for NYG4 of SOEC.

\begin{tabular}{|c|c|c|}
\hline Case & Case 1 & Case 2 \\
\hline Faraday Efficiency [\%] & 48 & 100 \\
\hline Enthalpy efficiency of electrolysis [-] & \multicolumn{2}{|c|}{0.900} \\
\hline $\mathrm{CO}$ conversion efficiency $[-]$ & \multicolumn{2}{|c|}{0.600} \\
\hline Operating temperature $\left[{ }^{\circ} \mathrm{C}\right]$ & \multicolumn{2}{|c|}{800} \\
\hline Applied voltage [V] & \multicolumn{2}{|c|}{2.83} \\
\hline Current density $\left[\mathrm{A} \mathrm{cm}^{-2}\right]$ & \multicolumn{2}{|c|}{0.180} \\
\hline Power density [ $\left.\mathrm{W} \mathrm{cm}^{-2}\right]$ & \multicolumn{2}{|c|}{0.509} \\
\hline $\mathrm{CO}$ production rate $\left[\mu \mathrm{mol} \mathrm{s}^{-1} \mathrm{~cm}^{-2}\right]$ & 0.448 & 0.933 \\
\hline $\mathrm{O}_{2}$ production rate $\left[\mu \mathrm{mol} \mathrm{s}^{-1} \mathrm{~cm}^{-2}\right]$ & 0.224 & 0.467 \\
\hline
\end{tabular}

Table 4. Calculated results from the iACRES feasibility study based on experimental data for NYG4 of SOEC.

\begin{tabular}{ccc}
\hline Case & Case 1 & Case 2 \\
\hline Faraday Efficiency [\%] & 48 & 100 \\
$\mathrm{CO}_{2}$ emission-reduction rate [\%] & & 30.0 \\
SOEC electrical demand [MWe] & 423 & 203 \\
SOEC heat demand [MWth] & 28.8 & 28.8 \\
Required SOEC surface area [m $\left.{ }^{2}\right]$ & $8.30 \times 10^{4}$ & $3.98 \times 10^{4}$ \\
Thermal demand from HTGR [MWth] & 968 & 480 \\
\hline
\end{tabular}

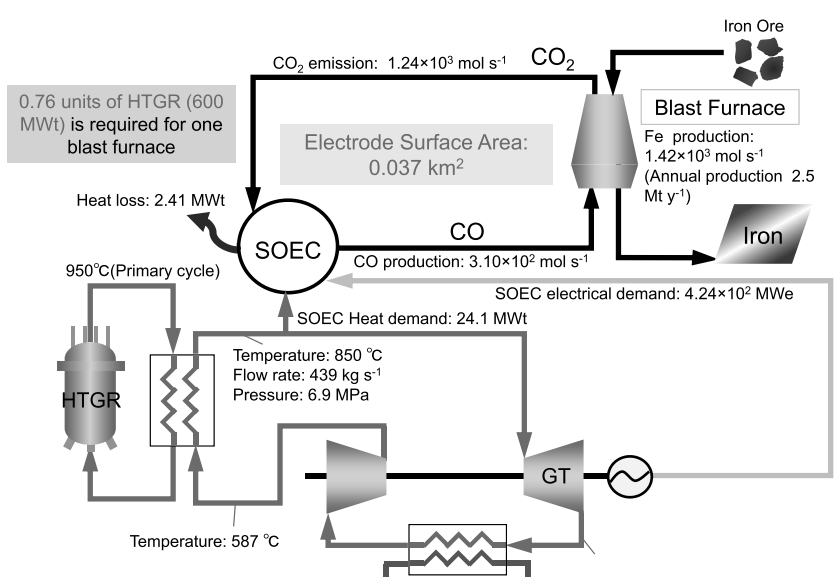

Fig. 12. Total material and energy balances of the iACRES system.

\section{Conclusion}

$\mathrm{CO}_{2}$ electrolysis was demonstrated using an MS-SOEC extendable to a large surface area. I-V curves and gasanalysis data revealed that $\mathrm{CO}_{2}$ electrolysis occurred on the MS-SOEC cell. $\mathrm{CO}$ and $\mathrm{O}_{2}$ production rates of 0.88 and $0.44 \mu \mathrm{mol} \mathrm{cm}^{-2} \mathrm{~s}^{-1}$, respectively, were obtained at $800^{\circ} \mathrm{C}$ by applying $2.0 \mathrm{~V}$ between the cathode and the reference. CO Faraday efficiencies of up to $48 \%$ were observed at 800 and $900^{\circ} \mathrm{C}$. Gas leakage in the cell was detected; remediation of this leakage by improving the layer-production process is required to achieve a value close to $100 \%$. A feasibility evaluation of iACRES based on a blast-furnaceclass ironmaking system using HTGR outputs revealed that an MS-SOEC surface area of $8.30 \times 10^{4}$ and $3.98 \times 10^{4} \mathrm{~m}^{2}$, and 968 and 480 MWth of HTGR thermal output under Faraday efficiency of $48 \%$ and $100 \%$, respectively, are required to reduce $\mathrm{CO}_{2}$ emissions by $30.0 \%$. We expect that MS-SOEC can be used to extend the surface area of SOEC for an iACRES system, and that iACRES with MSSOEC will contribute to realizing low-carbon ironmaking through recycling $\mathrm{CO}_{2}$ and reducing $\mathrm{CO}_{2}$ emissions into the atmosphere.

\section{Acknowledgments}

This work was supported by JSPS KAKENHI Grant Numbers JP16H04644, JP15K14300. The authors sincerely thank Dr. Masaya Ito (NGK Spark Plug Co., Ltd.) for the MS-SOEC design and production, Mr. Yuhei Ohide (TOCALO Co., Ltd.) for SOEC production, Mr. Shinichi Okuda (Nippon Seisen Co., Ltd.) for supply of the metal base, and Dr. Takuto Kushi (Tokyo Gas Co., Ltd.) and Prof. Isao Saeki (Muroran Institute of Technology) for suggestions during the development of the MS-SOEC.

\section{REFERENCES}

1) Y. Kato: ISIJ Int., 50 (2010), 181

2) Y. Kato: ISIJ Int., 52 (2012), 1433

3) Y. Kato: Nucl. Eng. Des., 271 (2014), 79.

4) A. Dipu, J. Ryu and Y. Kato: ISIJ Int., 52 (2012), 1427.

5) G. Fujii, J. Ryu, K. Yoshida, T. Yano and Y. Kato: ISIJ Int., 55 (2015), 387.

6) M. C. A. Nepomuceno and Y. Kato: Energy Procedia, 131 (2017), 101.

7) X. Yue and J. T. S. Irvine: J. Electrochem. Soc., 159 (2012), F442.

8) K. Kunitomi, X. Yan, T. Nishihara, N. Sakaba and T. Mouri: J. Nucl. Sci. Technol., 39 (2007), No. 1, 9.

9) JFE 21st Century Foundation: An Introduction to Iron and Steel Processing, Chapter 2D Blast Furnace, JFE 21st Century Foundation, Tokyo, (1997), http://www.jfe-21st-cf.or.jp/chapter_2/2d_2. html, (accessed 2019-02-15). 